\title{
Dampak Ekonomi Ekowisata Air Terjun Suranadi Terhadap Masyarakat Lokal Di Desa Jatiluwih
}

I Putu Agus Mahendra Suryajayaa, 1, I Made Adikampana, 2

1agusmahendra1107@gmail.com, adikampana@unud.ac.id

a Program Studi Sarjana Destinasi Pariwisata, Fakultas Pariwisata,Universitas Udayana, Jl. Dr. R. Goris, Denpasar, Bali 80232 Indonesia

\section{Abstract}

Tourism activity is one of process that has an important role in development of an area. One of the tourist attractions in Bali Island is Suranadi Waterfall Ecotourism Gunungsari area, Jatiluwih village. Time flies so that Suranadi Waterfall is visited by tourist. Based on the tourism situation, Suranadi waterfall ismanaged by local society through creating group. The research aims to determine of development Suranadi waterfall Ecotourism and economic impact on local society at Village Jatiluwih through several stages are Identification, Products, level of tourist visit, involvement of local society and impact on income, employment opportunities for society at Gunung Sari Umakayu area. The next stage is assessed by distributing questionnaires to local society at Gunung Sari Umakayu area, Jatiluwih village. Data collection techniques areobservation, interview, questionnaires, literature study and documentation. The techniques of determining informant Purposive Sampling.

The analysis technique uses descriptive qualitative. The result of research indicates that involvement society through tourism development is at incentive participation and functional participation stages. The impact on society income after development Suranadi waterfall ecotourism, changes income, the average amount of income per month, the amount of expenditure to fulfill daily need has increased.The impact of employment opportunities after development of Jatiluwih waterfall ecotourism, amount of jobless is reduced inside and outside group, society has side job is increased that is in group only.

Keywords: Impact, Socio-Economic, Ecotourism, Society

\section{PENDAHULUAN}

\subsection{Latar Belakang}

Sektor pariwisata merupakan salah satu sektor yang memiliki kontribusi dalam penerimaan pendapatan dan penyerapan tenaga kerja, itu disebabkan karana adanya kunjungan wisatawan ke suatu daya tarik wisata. Kedatangan wisatawan ke suatu destinasi wisata akan membuka peluang kerja bagi masyarakat. Bali terkenal sebagai tujuan pariwisata dengan keunikan berbagai hasil seni budayanya, Pulau Bali memiliki banyak tempat wisata yang menarik. Salah satunya adalah daya tarik wisata alam di Desa Jatiluwih yang terletak di Kecamatan Penebel sebelah utara Kota Tabanan. Banyaknya wisatawan yang datang mengujungi Desa Jatiluwih perkembangan pariwisata disana juga semakin maju, terbukti di Desa Jatiluwih sudah banyak dibangun berbagai sarana akomodasi seperti villa, restoran dan salah satunya lagi yaitu ekowisata Air Terjun Suranadi. Wisatawan yang berkunjung ke Desa Jatiluwih dan khususnya ke Dusun Gunung Sari Umakayu mengakibatkan adanya perubahan terhadap tingkat dampak ekonomi Masyarakat lokal Desa Jatiluwih kususnya Dusun Gunung Sari Umakayu, untuk itu penelitian ini bertujuan mengetahui pengembangan ekowisata Air Terjun Suranadi dan dampak ekonomi terhadap masyarakat lokal Dusun Gunung Sari Umakayu Desa Jatiluwih.

\section{TINJAUAN PUSTAKA \\ 2.1 Penelitian Sebelumnya}

Penelitian mengenai dampak pengembangan pariwisata yang dapat dikaji penelitian yang dilakukan oleh Dritasto dan Ayu (2013) yang berjudul Analisis Dampak Ekonomi Wisata Bahari Terhadap Pendapatan Masyarakat di Pulau Tidung. Penelitian ini membahas tentang bagaimana dampak ekonomi yang timbul akibat dari pengembangan pariwisata. Pendapatan masyarakat menjadi meningkat dan lapangan kerja terbuka lebar di kawasan wisata tersebut. Banyak masyarakat lokal memanfatkan peluang tersebut dengan membuka usaha sendiri seperti jasa penginapan (homestay), memiliki kios warung, jasa catering, jasa rumah makan, jasa pemandu wisata, jasa penyewaan alat - alat selam, penyewaan trasportasi kapal dan memiliki toko souvenir.

Penelitian terdahulu berikutnya dalam Rusdiana dkk (2014) dengan judul Pemanfaatan Potensi Desa Jatiluwih Kecamatan 
Penebel Kabupaten Tabanan Sebagai daya tarik wisata Alam (Tinjauan Geografi Pariwisata). Obyek wisata alam Desa Jatiluwih, Kecamatan Penebel, Kabupaten Tabanan, dengan tujuan untuk mendeskripsikan potensi wisata di Desa Jatiluwih. Mendukung pengembangan daya tarik wisata alam Jatiluwih, mendeskripsikan partisipasi masyarakat Desa Jatiluwih terhadap pengembangan daya tarik wisata alam Jatiluwih. Populasi dalam penelitian ini adalah Masyarakat Desa Jatiluwih. Pengumpulan data primer menggunakan metode observasi, metode kuesioner, dan metode pencatatan dokumen, selanjutnya data dianalisis dengan menggunakan analisis deskriptif.

Persamaan dalam penelitian sebelumnya yaitu sama - sama meneliti mengenai pengembangan suatu daya tarik wisata terhadap kehidupan ekonomi masyarakat lokal. Pada penelitian yang terakhir meneliti tentang potensi Desa sebagai daya tarik wisata alam dengan tujuan mendukung pengembangan potensi wisata yang mendeskripsikan partisipasi masyarakat, sedangkan dalam penelitian ini meneliti tentang dampak ekonomi ekowisata Air Terjun Suranadi terhadap masayarakat lokal di Desa Jatiluwih dan khususnya di Dusun Gunung Sari Umakayu. Perbedaan dalam penelitian ini yaitu terletak pada lokus penelitian.

\subsection{Deskripsi Konsep}

\subsubsection{Konsep Dampak}

Menurut Soekanto (2006) secara etimologis dampak memiliki pengertian sebuah efek dari fenomena sosial yang terjadi dalam kehidupan Masyarakat. Soekanto (2006) menambahkan bahwa dampak sosial mempunyai dua sifat yaitu bersifat positif dan negatif. Menurut Faizun (2009) dampak adalah perubahan - perubahan yang terjadi terhadap Masyarakat sebagai komponen dalam lingkungan hidup sebelum ada kegiatan pariwisata dan setelah ada kegiatan pariwisata. Pitana dan Gayatri, (2009) dampak pariwisata terhadap Masyarakat dan daerah tujuan wisata mencangkup dampak terhadap sosial budaya dan dampak terhadap lingkungan. Kaitan dengan penelitian ini, yang dimaksud dengan dampak adalah perubahan - perubahan yang ditimbulkan dari dampak ekonomi ekowisata Air Terjun Suranadi terhadap Masyarakat lokal Desa jatiluwih kususnya Dusun Gunung Sari Umakayu.
Dampak pariwisata terhadap kondisi sosial ekonomi Masyarakat lokal dapat di katagorikan menjadi delapan kelompok besar Cohen 1984 ( dalam Pitana dan Gayatri, (2009) 1. Dampak terhadap penerimaan devisa. 2. Dampak terhadap pendapatan Masyarakat. 3. Dampak terhadap kesempatan kerja. 4. Dampak terhadap harga - harga. 5. Dampak terhadap distribusi manfaat/keuntungan. 6. Dampak terhadap kepemilikan. 7. Dampak terhadap pembangunan pada umumnya. 8. Dampak terhadap pendapatan pemerintah. Konsep ini digunakan untuk membahas permasalahan tentang dampak sosial ekonomi Masyarakat Dusun Gunung Sari Umakayu Desa Jatiluwih.

Pengaruh ekonomi pariwisata adalah manfaat atau kontribusi kegiatan pariwisata terhadap ekonomi suatu wilayah atau masyarakat lokal Prechthing (1987) dalam Adikampana (2008). Kontribusi pariwisata terhadap ekonomi Masyarakat dapat diklasifikasikan menjadi dua, yaitu kontribusi primer dan kontribusi sekunder. Kedua bagian kontribusi ini berhubungan erat dengan pembelanjaan pengunjung di destinasi pariwisata. Dalam penelitian ini kontribusi pariwisata dijelaskan sebagai spending atau pengeluaran wisatawan Ekowisata Air Terjun Suranadi dibagi menjadi tiga pengeluaran. Pengeluaran untuk tiket masuk, pengeluaran untuk produk dan pengeluaran untuk pemandu wisata (guide).

\subsubsection{Konsep Pengembangan Daya Tarik Wisata}

Pengertian pengembangan daya tarik wisata Oka A Yoeti dalam Agus Alim (2002) menyatakan bahwa pengembangan daya tarik wisata mencangkum pengembangan produk baru yaitu usaha yang dilakukan secara sadar dan berencana. Untuk memperbaiki produk yang sedang berjalan atau menambah jenis produk yang di hasilkan maupun di pasarkan.

Pengembangan daya tarik wisata harus dapat menciptakan "product style " yang baik dimana di antaranya adalah : daya tarik itu harus menarik untuk disaksikan maupun dipelajari, mempunyai kususan dan berbeda dari daya tarik lain, dalam penelitian ini pengembangan daya tarik wisata merupakan aktivitas untuk menata suatu DTW dengan menambahkan dan memajukan dengan baik agar daya tarik wisata menarik dan ramai di kunjungi oleh wisatawan. 
Menurut Mill (2000) dalam Made Satria (2013) pengembangan pariwisata bertujuan untuk memberikan keuntungan baik wisatawan maupun komonitas tuan rumah. Pembangunan pariwisata diharapkan mampu meningkatkan taraf hidup Masyarakat melalui keuntungan secara ekonomi yang dibawa ke kawasan tersebut. Pengembangan pariwisata melalui penyediaan fasilitas infrastruktur, wisatawan , dan penduduk setempat akan saling di untungkan. Pengembangan tersebut hendaknya sangat memperhatikan berbagai aspek, seperti: aspek budaya, aspek sejarah, dan aspek ekonomi pada daerah tujuan wisata. Dalam penelitian ini pengembangan diartikan sebagai kegiatan untuk menjadikan Air Terjun Suranadi sebagai daya tarik ekowisata dengan mengembangkan potensi wisata serta memberdayakan Masyarakat lokal dalam semua aktifitas pengembangan.

\subsubsection{Konsep Ekowisata}

Menurut (Fennel, 1999) dalam Sukma Arida (2009) ekowisata merupakan wisata berbasis alam yang berkelanjutan denga fokus pengalaman dan pendidikan tentang alam, dikelola dengan sistem pengelolaan tertentu dan memberi dampak negatif paling rendah terhadap lingkungan, tidak bersipat konsumtif dan beroentasi pada lokal ( dalam hal kontrol, manfaat yang dapat diambil dari kegiatan usaha).

\subsubsection{Tipologi Partisipasi Masyarakat}

Pretty dalam Pretty's Typology of Participation 1995. Tipologi partisipasi yang dimaksud merupakan urutan yang hierarkis dari tipe partisipasi yang minimalis sampai partisipasi yang optimal. Pretty, (1995) membagi bentuk partisipasi Masyarakat tersebut ke dalam tujuh tipologi partisipasi beserta karakteristiknya masing-masing yaitu: 1. Tipologi Partisipasi Manipulatif, karakteristiknya partisipasi hanya sebuah tipuan: 'Masyarakat' hanya terwakilkan dalam kelembagaan pariwisata, namun tidak mempunyai kekuatan. 2. Tipologi Partisipasi Pasif, karakteristiknya Masyarakat hanya berpartisipasi pada kejadian yang telah berlangsung atau hal-hal yang telah diputuskan secara sepihak oleh manajeman yang hanya berkonsultasi dengan pihak eksternal. 3. Tipologi Partisipasi Konsultatif, karakteristiknya Masyarakat berpartisipasi dengan berkonsultasi atau menjawab pertanyaan yang diajukan pihak eksternal. 4 . Tipologi Partisipasi Insentif, karakteristiknya Masyarakat berpartisipasi dengan memberikan sumber daya yang mereka miliki untuk mendapatkan materi insentif. 5. Tipologi Partisipasi Fungsional, karakteristiknya Masyarakat dapat membentuk kelompokkelompok untuk memenuhi tujuan proyek. 6 . Tipologi Partisipasi Interaktif, karakteristiknya Masyarakat berpartisipasi dalam analisis bersama, pengembangan rencana dan penguatan institusi lokal yang dipandang sebagai hak Masyarakat. 7. Tipologi Partisipasi Mandiri, karakteristiknya Masyarakat berpartisipasi dengan melakukan segala sesuatunya secara inisiatif dan independen untuk mengubah sistem yang ada. ( Pretty, 1995).

\section{METODE PENELITIAN}

Penelitian ini dilakukan di Banjar Gunung Sari Umakayu, Desa Jatiluwih. kecamatan Penebel, Kabupaten Tabanan, penelitian ini adalah salah satu daya tarik wisata yang ada di Jatiluwih.

Adapun ruang lingkup penelitian meliputi : 1 . Produk Ekowisata Air Terjun Suranadi (potensi, daya tarik, fasilitas, aksesibilitas). 2. Tingkat kunjungan wisatawan Ekowisata Air Terjun Suranadi. 3. Keterlibatan Masyarakat dalam pengembangan Ekowisata Air Terjun Suranadi.

Dampak ekonomi sebelum dan sesudah pengembangan Ekowisata Air Terjun Suranadi di Desa Jatiluwih, yang meliputi : 1. Dampak terhadap pendapatan Masyarakat. 2. Dampak terhadap kesempatan kerja.

Jenis data yang dikumpulkan dalam penelitian ini yaitu data kualitatif Creswell (1998) dalam Juliansyah (2011) gambaran umum ekowisata Air Terjun Suranadi yang ada di Desa Jatiluwih. Data kuantitatif menurut Deszin dan Lincoln dalam Juliansyah (2011). jumlah kunjungan wisatawan berkunjung ke Ekowisata Air Terjun Suranadi, jumlah Masyarakat di Desa Jatiluwih berdasarkan mata pencaharian dan hasil penelitian dari kuesioner. Sumber data dalam penelitian ini data primer Menurut Sugiyono (2010). Data primer adalah data yang didapat dari wawancara mendalam ke Masyarakat diluar kelompok dan Masyarakat yang didalam kelompok. 
Data sekunder Nasir (1988), data yang diperoleh dari literatur - literatur atau buku buku kepustakaan, dokumen dan arsip, yakni seperti jumlah kunjungan wisatawan, tinjauan kepustakaan, serta data lainnya yang berkaitan dengan penelitian. Teknik pengumpulan data yang digunakan yakni observasi, wawancara, studi kepustakaan, kuesioner dan dokumentasi. Tekninik Penentuan informan dalam penelitian ini teknik yang digunakan purposive sampling. Menurut Juliansyah (2011), teknik penentuan informan ini di lakukan Informan dalam penelitian adalah orang atau pelaku yang benar-benar tahu dan menguasai masalah, dengan menggunakan metode penelitian kualitatif, dari mulai kepala Desa setempat untuk mengulas informsi, pihak pengelola untuk mengetahui jumlah kunjungan dan juga pengembangan ekowisata Suranadi dan tokohtokoh Masyarakat yang terkait dalam penelitian. Tekninik analisisi data Penelitian ini menggunakan analisis deskriptif kualitatif, analisis ini akan melakukan penyederhanaan dan pengelompokan data yang terkumpul, baik yang berupa ide ataupun ungkapan dari hasil kuesioner, wawancara dan pengelompokan data observasi.

\section{HASIL DAN PEMBAHASAN \\ 4.1 Gambaran Umum}

Penelitian ini dilakukan di Desa Jatiluwih, Kecamatan Penebel, Kabupaten Tabanan. Tepatnya pada Dusun Gunung Sari Umakayu. Lokasi penelitian ini terletak $26 \mathrm{Km}$ ke arah utara dari Kota Tabanan atau $13 \mathrm{Km}$ ke arah utara dari kota kecamatan Penebel dan 49 $\mathrm{Km}$ ke ibukota Provinsi. Desa dengan jarak tempuh kurang lebih 35 menit dari kota Kecamatan Penebel sekitar $13 \mathrm{Km}$ dan dari Kabupaten dengan jarak tempuh kurang lebih 50 menit atau sekitar $26 \mathrm{Km}$. Dimana dari segi pemerintahan Desa Jatiluwih terbagi atas 8 Banjar atau Dusun yaitu: Br. Dinas Kesambi, Br. Dinas Kesambahan Kaja, Br. Dinas Kesambahan Kelod, Br. Dinas Jatiluwih Kangin, Br. Dinas Jatiluwih Kawan, Br. Dinas Gunungsari Desa, Br. Dinas Gunungsari Umakayu, Br. Dinas Gunungsari Kelod. Daya Tarik Desa Jatiluwih dengan persawahan terasering dan pemandangan yang masih sangat alami, Selain itu di kawasan Desa Jatiluwih ini terdapat daya tarik wisata yaitu Air Terjun yang berada tepatnya pada Dusun Gunung Sari Umakayu yang tidak kalah menariknya dari Daya tarik wisata unggulan lainya yang ada di Desa Jatiluwih.

\subsection{Pengembangan Ekowisata Air Terjun Suranadi}

Produk Ekowisata Air Terjun Suranadi ini meliputi adanya Potensi, Daya Tarik Wisata, Fasilitas, dan Aksesibilitas. 1. Potensi fisik dalam penelitian ini adalah alam yang menjadi basisnya seperti pada saat perjalanan ke Air Terjun melihat view pemandangan sawah dan hutan yang lebat dan sejuk, sehingga menjadi panorama Air Terjun yang indah. Potensi Nonfisik seperti potensi ptensial sosial maupun budaya Masyarakat setempat yang menarik untuk di lihat dan diketahui. Salah satunya seperti foto prawedding. dapat dilihat bagian dari kebudayaan Masyarakat setempat dalam bercocok tanam secara masih tradisional. Keunggulan ataupun daya tarik wisata ini meliputi selain tempat wisatanya yang indah dan masih tergolong asri dan terjaga, Air Terjun Suranadi ini juga jauhnya dari kebisingan yang di sebabkan oleh kendaran maupun Masyarakat dan yang lebih pentingnya lagi daya tarik wisata Air Terjun Suranadi ini minim dari polusi, beberapa faktor yang mempengaruhi daya tarik dapat dilihat dari kebudayaan, dijelaskan bahwa Masyarakat Desa Jatiluwih maupun Dusun Gunungsari sendiri memiliki kesenian dan kebudayaan diantaranya seperti seni pertunjukan, joget bumbung, topeng dan adanya alat kesenian berupa gong, rindik yang dibuat dari kayu. Selain itu sistem religi Masyarakat seperti kegiatan seremonial Agama (Ngaben).

Fasilitas dalam penelitian ini untuk memenuhi kebutuhan wisatawan yang berkunjung ke daya tarik wisata Air Terjun Suranadi, pihak pengelola Air Terjun Suranadi membuat berbagai fasilitas yang ada baik dari sarana akomodasi, jasa makanan dan minuman, jasa transport dan usaha penunjang lainya. Dalam berkunjung ke ekowisata Air Terjun Suranadi wisatawan dapat menikmati fasilitas fasilitas yang sudah di sediakan di Air Terjun Suranadi sendiri. Adanya beberapa fasilitas dari ekowisata Air Terjun Suranadi ini yang di buat langsung dari anggota kelompok yang ikut serta untuk menyediakan fasilitas yang ada berupa homestay dua kamar yang berada tidak jauh dari tempat parkir. 
Adapun tingkat aksesibilitas Daya tarik wisata dapat diukur berdasarkan : A. Kondisi Jalan, Kondisi jalan dalam hal ini ada dua yaitu kondisi jalan utama (jalan desa), dan kondisi jalan setapak menuju daya tarik wisata. B. Jarak dan Waktu Tempuh menuju DTW jika di lihat dari pusat kota provinsi berjarak $49 \mathrm{~km}$, dengan waktu tempuh sekitar kurang lebih 1 jam. dari kota Tabanan $26 \mathrm{~km}$ dengan jarak tempuh kurang lebih 50 menit. C. Biaya Pengukuran biaya disini biaya masuk kekawasan Desa jatiluwih dan memasuki daya tarik wisata. D. Konstelasi DTW Air Terjun Suranadi ini sangat strategis dimana masih tercangkup dalam kawasan atau Daya tarik wisata lainya yang ada di kwasan Jatiluwih,

Berikut merupakan Tabel data kunjungan wisatawan dari tahun 2013 - 2017 ke Daya Tarik Ekowisata Air Terjun Suranadi Dusun Gunungsari Umakayu Desa Jatiluwih.

\section{Tabel.1 Data Kunjungan Wisatawan Asing Air Terjun Suranadi}

\begin{tabular}{|l|c|c|c|c|c|}
\hline \multicolumn{1}{|c|}{ Tahun } & $\begin{array}{c}2013 \\
\text { Jiwa }\end{array}$ & $\begin{array}{c}2014 \\
\text { Jiwa }\end{array}$ & $\begin{array}{c}2015 \\
\text { Jiwa }\end{array}$ & $\begin{array}{c}2016 \\
\text { Jiwa }\end{array}$ & $\begin{array}{c}2017 \\
\text { Jiwa }\end{array}$ \\
\hline Januari & & & & 56 & 67 \\
\hline Februari & & 16 & & 16 & 70 \\
\hline Maret & & 28 & 10 & & 61 \\
\hline April & & 24 & 42 & 28 & 63 \\
\hline Mei & & 88 & 10 & 36 & 50 \\
\hline Juni & & 76 & & 28 & 80 \\
\hline Jili & & 29 & 16 & 48 & 85 \\
\hline Agustus & 25 & & 28 & & 60 \\
\hline September & 46 & & 10 & & 43 \\
\hline Oktober & 2 & 14 & 52 & & 75 \\
\hline November & 4 & 38 & 35 & & 81 \\
\hline Desember & & & & 78 \\
\hline
\end{tabular}

Sumber : Pengelola Ekowisata Air Terjun Suranadi 20018

Berdasarkan data Tabel, yang tercatat hanyalah wisatawan asing saja yang dicatat, untuk wisatawan lokalnya tidak ada tercatat, hanya saja wisatawan lokal di kenakan biaya parkir saja untuk bisa masuk ke areal Air Terjun. Jadi data kunjungan wisatawan dalam setiap tahunnya tidak sepenuhnya tercatat dengan baik sehingga seperti tabel diatas tidak sepenuhnya terisi dengan data kunjungan wisatawan. Sehingga tingkat kunjungan wisatawan yang didapatkan ke Ekowisata Air Terjun Suranadi tidak mengalami peningkatan atau

penurunan yang signipikan. Dari wisatawan asing yang datang ke Air Terjun di dominasi wisatawan asal Taiwan, Spanyol, Amerika dan Cina.

Keterlibatan Masyarakat Dalam Pengembangan Ekowisata Air Terjun Suranadi keterlibatan masyarakat ini mengacu pada konsep tipologi partisipasi Insentif dan Tipologi Partisipasi Fungsional, dimana keterlibatan masyarakat berpartisipasi dengan memberikan sumber daya yang mereka miliki untuk mendapatkan materi insentif. Masyarakat membentuk Kelompok - kelompok untuk memenuhi tujuan proyek, dilihat dari akses jalan menuju Air Terjun sudah bagus di perbaiki oleh masyarakat Dusun Gunungsari Uma Kayu, Kususnya kelompok Ekowisata Air Terjun Suranadi yang memberikan sumber daya yang mereka miliki. Dilihat dari perbaikan akses jalan menuju Daya tarik wisata, mempermudah wisatawan untuk berkunjung ke Air Terjun. Lahan parkir dari kebun Masyarakat yang ikut kelompok, dengan sengajanya dibersihkan separuh untuk lahan parkir kendaraan wisatawan yang ingin berkunjung.

\subsection{Dampak Ekonomi Sebelum Pengembangan Ekowisata Air Terjun Suranadi Dusun Gunung Sari Umakayu Desa Jatiluwih.}

Pendapatan sebelum berkembangnya Ekowisata Air Terjun Suranadi, dari hasil penelitian pada kuesioner sebelum berkembangnya Ekowisata Air Terjun Suranadi responden yang tidak merasakan terhadap pengaruh pendapatan yaitu diluar kelompok memiliki hasil tertinggi, nilai tertinggi dikaranakan yang menjawab tidak, mereka yang tidak ikut dalam kelompok namun dari hasil wawancara mendapatkan jawaban kelompok Ekowisata Air Terjun tersebut belum di kelola dengan baik.

Dampak Terhadap Jumlah Rata - Rata Pendapatan Masyarakat Perbulan Sebelum Berkembangnya Ekowisata Air Terjun Suranadi, menunjukan bahwa sebelum berkembangnya Ekowisata Air Terjun Suranadi, Masyarakat yang mendapatkan penghasilan rata - rata perbulan hampir sama dengan pendapatan masyarakat diluar maupun didalam kelompok ekowisata air terjun suranadi. Dalam penelitian ini dampak Ekowisata Air Terjun Suranadi terhadap jumlah rata - rata pengeluaran perbulan sebelum berkembangnya Ekowisata Air Terjun Suranadi. 
Rata - rata Pengeluaran didalam dan diluar kelompo 500.000 - 1000.000

Berdasarkan hasil penelitian menunjukan bahwa sebelum berkembangnya Ekowisata Air Terjun Suranadi, masyarakat Dusun Gunung Sari Umakayu Desa Jatiluwih didalam kelompok yang memiliki pengahsilan cukup untuk memenuhi kebutuhan sehari - hari menunjukan nilai terendah yaitu 3 orang dengan jumlah persentase 12\%, jumlah masyarakat didalam kelompok yang memiliki penghasilan kurang untuk memenuhi kebutuhan sehari - hari memiliki nilai tertinggi yaitu 22 orang dengan jumlah persentase $88 \%$ sedangkan masyarakat yang diluar kelompok memiliki penghasilan yang kurang untuk memenuhi kebutuhan sehari - hari memiliki nilai tertinggi yaitu 63 orang dengan jumlah persentase $84 \%$, yang memiliki penghasilan cukup untuk memenuhu kebutuhan sehari hari menunjukan nilai 12 orang dengan jumlah persentase $16 \%$.

Dampak Terhadap Kesempatan Kerja Pekerjaan Utama Masyarakat Dusun Gunung Sari Umakayu Sebelum Berkembangnya Ekowisata Air Terjun Suranadi Jatiluwih. Dalam penelitian ini kesempatan kerja dikelompokan menjadi tiga bagian yaitu pekerjaan sebelum berkembangnya Ekowisata Air Terjun Suranadi, pekerjaan sampingan sebelum berkembangnya Ekowisata Air Terjun Suranadi, usaha atau bisnis yang dimiliki sebelum berkembangnya Ekowisata Air Terjun Suranadi. Berdasarkan penelitian dilihat bahwa masyarakat Dusun Gunungsari Umakayu Desa Jatiluwih memiliki jenis - jenis pekerjaan yang berbeda - beda diantaranya yaitu ada yang sebagai petani, pedagang, PNS dan pekerjaan lainya, sebelum berkembangnya Ekowisata Air Terjun Suranadi. Masyarakat yang memiliki pekerjaan sampingan sebelum berkembanya ekowisata masyarakat diluar kelompok hanya 11 orang, didalam kelompok 18 orang. Jumlah pemilik usaha atau peluang bisnis didalam kelompok hanya 1 orang sedangkan diluar kelompok 5 orang.

\subsection{Dampak Ekonomi Sesudah Pengembangan Ekowisata Air Terjun Suranadi Dusun Gunung Sari Umakayu Desa Jatiluwih.}

Dampak ekonomi terhadap pengembangan pariwisata yang digunakan dalam penelitian ini yaitu dampak terhadap pendapatan masyarakat dan dampak terhadap kesempatan kerja. Dampak ekonomi Air Terjun Suranadi ini digunakan untuk mengetahui dampak yang dirasakan masyarakat didalam atau diluar kelompok sesudah adanya kelompok ekowisata Air Terjun Suranadi

\subsubsection{Pengeluaran Wisatawan Untuk Tiket Masuk, Produk dan Pemandu Wisata}

Pengeluaran yang dimaksud disini dibagi menjadi tiga pengeluaran beserta rentetan kontribusi pengeluaran tersebut. Untuk lebih jelasnya aka dijelaskan pada bagan.

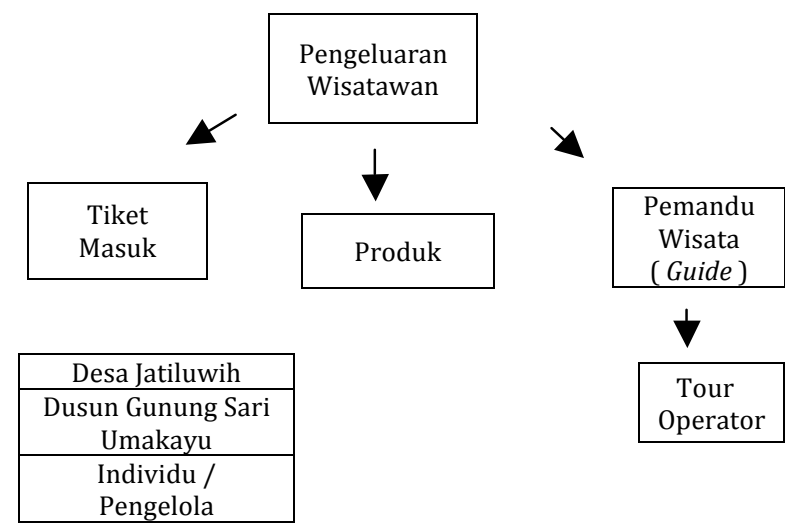

Sumber : Dari Hasil Penelitian 2017

Menurut hasil dari wawancara pengeluaran untuk tiket masuk di bagi menjadi tiga bagian yaitu untuk ke Desa Jatiluwih ke Dusun Gunungsari Umakayu dan ke individu, dari pemasukan tiket masuk yang masuk ke Desa Jatiluwih sebesar $10 \%$ dari wisatawan yang membeli tiket masuk ke Ekowisata Air Terjun Suranadi, hasil dari tiket masuk juga di bagi ke Dusun Gunung Sari Umakayu dengan persentase $5 \%$ sedangkan untuk individu atau pengelola dengan persentase 85\%. Pengeluaran tiket masuk untuk wisatawan dan pengeluaran tiket masuk untuk daya tarik wisata jadi ada dua pengeluaran untuk tiket masuk, disini yang dibagi pengeluaran tiket masuk yang masuk ke daya tarik Ekowisata Air Terjun Jatiluwih saja sedangkan tiket masuk untuk kawasan Jatiluwih untuk keseluruhannya lain lagi dan itu pemasukanya untuk ke Desa Jatiluwih gunanya untuk lahan parkir wisatawan yang ingin makan di restauran atau juga untuk wisatwan yang ingin berpoto di sawah terasering Jatiluwih.

Pengeluaran untuk produk disini yang dimaksud adalah Homestay, pengeluaran wisatawan untuk produk disini dibagi menjadi tiga bagian juga pemasukan ke Desa Jatiluwih, 
ke Dusun Gunung Sari Umakayu dan yang terakhi pemasukan ke individu atau pengelola kelompok, ke Desa Jatiluwih dengan jumlah persentase 15\% dan Dusun Gunung Sari Umakayu dengan persentase $10 \%$, sedangkan untuk individu dengan jumlah persentase $75 \%$. Pengeluaran wisatawan untuk produk disini mencangkup adanya pasilitas yang sudah disediakan, hidangan makanan dan minuman untuk wisatawan yang menginap di Homestay Ekowisata Air Terjun Suranadi.

Pengeluaran wisatawan yang dibawa untuk menginap di Homestay Ekowisata Air Terjun Suranadi ini Guide luar mendapat keuntungan dari idividu atau pengelola, atas jasa Guide yang mengajak wisatawan untuk menginap di Homestay Ekowisata Air Terjun Suranadi dengan persentase 30\%. Lain halnya dengan Tour Guide lokal tidak adanya pengeluaran wisatawan secara langsung atau berupa uang karana sudah tercangkup dalam tiket masuk dan Froduk yang dibeli oleh wisatawan, karanaTour Guide yang disediakan dari anggota kelompok Ekowisata Air Terjun Suranadi.

\subsubsection{Dampak Terhadap Pendapatan Masyarakat}

Dalam penelitian ini dampak ekonomi dalam pengembangan Ekowisata Air Terjun Suranadi di kelompokan menjadi dua bagian yaitu pendapatan masyarakat sesudah pengembangan Ekowisata, dampak terhadap kesempatan kerja sesudah pengembangan ekowisata,didalam dan diluar, kelompok Ekowisata Air Terjun Suranadi.

Dampak Ekonimi Sesudah Pengembangan Ekowisata Air Terjun Suranadi Terhadap Pendapatan Masyarakat.

\section{Tabel 2. Pendapatan masyarakat sesudah adanya kelompok Ekowisata Air Terjun Suranadi.}

\begin{tabular}{|l|c|c|c|c|}
\hline $\begin{array}{c}\text { Pendapatan } \\
\text { Sesudah } \\
\text { Berkembangnya } \\
\text { Air Terjun } \\
\text { Suranadi }\end{array}$ & \multicolumn{2}{|c|}{ Di Dalam } & \multicolumn{2}{c|}{ Di Luar } \\
\cline { 2 - 5 } & $\begin{array}{c}\text { Jumlah } \\
\text { Responden }\end{array}$ & $\begin{array}{c}\text { Persentasee } \\
(\%)\end{array}$ & $\begin{array}{c}\text { Jumlah } \\
\text { Responden }\end{array}$ & $\begin{array}{c}\text { Persentase } \\
(\%)\end{array}$ \\
\hline Ya & 25 & 100 & 18 & 24 \\
\hline Tidak & 0 & 0 & 57 & 76 \\
\hline Jumlah total & 25 & 100 & 75 & 100 \\
\hline
\end{tabular}

Sumber : Hasil Penelitian 2017

Menurut hasil penelitian pada kuesioner sesudah berkembangnya Ekowisata Air Terjun Suranadi responden yang tidak merasakan terhadap pengaruh pendapatan yaitu diluar kelompok memiliki hasil tertinggi, nilai tertinggi dikaranakan yang menjawab tidak, mereka yang tidak ikut dalam kelompok namun dari hasil sebelum berkembangnya Ekowisata Air Terjun Suranadi dan setelah berkembang adanya sedikit perubahan meskipun tidak signifikan .

Dampak Terhadap Jumlah Rata - Rata

Pendapatan Masyarakat Perbulan Sesudah Berkembangnya Ekowisata Air Terjun Suranadi. Dalam penelitian ini menggunakan dampak pengembangan pariwisata di Dusun Gunungsari Umakayu Desa Jatiluwih terhadap jumlah rata - rata pendapatan perbulan sesudah berkembangnya daya tarik Ekowisata Air Terjun Suranadi, jumlah rata - rata pendapatan perbulan dikelompokan menjadi empat bagian mulai dari pendapatan 500.000 sampai lebih dari 2.500.000.

Tabel 3. Rata - Rata Pendapatan Masyarakat Perbulan Sesudah Berkembang

\begin{tabular}{|l|c|c|c|c|}
\hline $\begin{array}{c}\text { Rata - Rata } \\
\text { Pendapatan } \\
\begin{array}{c}\text { Sesudah } \\
\text { Berkembangnya } \\
\text { Air Terjun } \\
\text { Suranadi }\end{array}\end{array}$ & $\begin{array}{c}\text { Jumlah } \\
\text { Responden }\end{array}$ & $\begin{array}{c}\text { Persentase } \\
(\%)\end{array}$ & $\begin{array}{c}\text { Jumlah } \\
\text { Responden }\end{array}$ & $\begin{array}{c}\text { Persentase } \\
(\%)\end{array}$ \\
\cline { 2 - 5 } $\begin{array}{l}500.000 \\
1000.000\end{array}$ & 6 & 24 & 23 & 31 \\
\hline $\begin{array}{l}1.000 .000 \\
2000.000\end{array}$ & 12 & 48 & 42 & 56 \\
\hline $\begin{array}{l}2.000 .000 \\
2.500 .000\end{array}$ & 7 & 28 & 10 & 13 \\
\hline $\begin{array}{l}2.500 .000 \\
\text { Lebih }\end{array}$ & 25 & 100 & 75 & 100 \\
\hline Jumlah total
\end{tabular}

Sumber : Hasil Penelitian 2017

Setelah berkembangnya Ekowisata Air Terjun Suranadi, Pada Tabel menunjukan bahwa berkembangnya Ekowisata Air Terjun Suranadi, Dari hasil penelitian pada kuisioner pertanyaan dibagi dua sempel masyarakat didalam kelompok dan diluar kelompok, terjadinya peningkatan pengahasilan diluar kelompok setelah berkembang, masyarakat didalam kelompok yang dulunya hanya sebagai petani saja kini mendapatkan pengahsilan dari penyewaan hoome stay secara bergilir yang dilakukan oleh kelompok, dan pendapatan masyarakat yang meningkat diperoleh dari luar kelompok, dari hasil wawancara masyarakat yang dulunya hanya petani kini memiliki wawasan, bertemu langsung dengan wisatawan asing dan memiliki pekerjaan seperti 
mendapatkan kerja direstauran, guide dan menjadi pekerja lahan karcis untuk masuk wilayah Jatiluwih.

Jumlah Rata - Rata Pengeluaran Perbulan Sesudah Berkembangnya Daya Tarik Ekowisata Air Terjun Suranadi. Dalam penelitian ini dampak Ekowisata Air Terjun Suranadi terhadap jumlah rata - rata pengeluaran perbulan setelah berkembangnya Ekowisata Air Terjun Suranadi dikelompokan menjadi empat bagian yaitu dari pengeluaran 500.000 - 2.500 .000 hingga lebi. Dalam penelitian ini, digunakan untuk mengetahui pengeluaran rata - rata perbulan sesudah berkembangnya Ekowisata Air Terjun Suranadi.

Tabel 4. Rata - Rata Pengeluaran Masyarakat Perbulan Sesudah Berkembang

\begin{tabular}{|l|c|c|c|c|}
\hline $\begin{array}{c}\text { Rata - Rata } \\
\text { Pengeluara } \\
\text { n Sesudah }\end{array}$ & \multicolumn{2}{|c|}{ Di Dalam } & \multicolumn{2}{c|}{ Di Luar } \\
\cline { 2 - 5 } $\begin{array}{c}\text { Berkemban } \\
\text { ya Air } \\
\text { Terjun } \\
\text { Suranadi }\end{array}$ & $\begin{array}{c}\text { Jumlah } \\
\text { Responde } \\
\mathrm{n}\end{array}$ & $\begin{array}{c}\text { Persenta } \\
\text { se } \\
(\%)\end{array}$ & $\begin{array}{c}\text { Jumlah } \\
\text { Responde } \\
\mathrm{n}\end{array}$ & $\begin{array}{c}\text { Persenta } \\
\text { se } \\
(\%)\end{array}$ \\
\hline $\begin{array}{l}500.000- \\
1000.000\end{array}$ & 8 & 32 & 29 & 39 \\
\hline $\begin{array}{l}1.000 .000- \\
2000.000\end{array}$ & 14 & 56 & 37 & 49 \\
\hline $\begin{array}{l}2.000 .000- \\
2.500 .000\end{array}$ & 3 & 12 & 7 & 9 \\
\hline $\begin{array}{l}2.500 .000 / \\
\text { Lebih }\end{array}$ & 0 & 0 & 2 & 3 \\
\hline Jumlah total & 25 & 100 & 75 & 100 \\
\hline
\end{tabular}

Sumber : Hasil Penelitian 2017

Berdasarkan Tabel menunjukan bahwa sesudah berkembangnya Ekowisata Air Terjun Suranadi, Jika dibandingkan dengan sebelum berkembangnya Ekowisata Air Terjun Suranadi, hal ini dikaranakan, setelah berkembangnya Ekowisata Air Terjun Suranadi masyarakat yang didalam kelompok mengajak gaide untuk kerjasama dan membuka usaha bersama untuk membuat hidangan untuk wisatawan yang berkunjung, sedangkan masyarakat yang diluar kelopok meskipun sedikit yang mendapatkan ibasnya dari pengembangan Ekowisata Air Terjun, measyarakat membuka usaha warung kecil - kecilan dan dari wawancara berpengaruh dengan adanya wisatawan asing mebuat sedikit gaya hidup anak - anak mereka berubah.

Tabel 5. Kecukupan Pendapatan Masyarakat Sesudah Berkembang

\begin{tabular}{|c|c|c|c|c|}
\hline Kecukupan & \multicolumn{2}{|c|}{ Di Dalam } & \multicolumn{2}{c|}{ Di Luar } \\
\cline { 2 - 5 } Pendapatan & Jumlah & Persenta & Jumlah & Persenta \\
Sesudah & Responde & se & Responde & se \\
Berkembangn & $\mathrm{n}$ & $(\%)$ & $\mathrm{n}$ & $(\%)$ \\
ya Air Terjun & & & & \\
\hline
\end{tabular}

\begin{tabular}{|l|c|c|c|c|}
\hline \multicolumn{1}{|c|}{ Suranadi } & & & & \\
\hline Ya & 23 & 92 & 19 & 25 \\
\hline Tidak & 2 & 8 & 56 & 75 \\
\hline Jumlah Total & 25 & 100 & 75 & 100 \\
\hline
\end{tabular}

Sumber : Hasil Penelitian 2017

Menurut penelitian dari hasil kuesioner, bahwa setelah berkembangnya Air Terjun Suranadi, didalam kelompok masyarakat mengalami peningkatan begitu juga dengan diluar kelompok meskipun tidak begitu besar namun setidaknya mencukupi kebutuhan sehari - hari mereka.

\subsubsection{Dampak Terhadap Kesempatan Kerja}

Dalam penelitian ini dampak terhadap kesempatan kerja sesudah berkembangnya Ekowisata Air Terjun Suranadi dibagi menjadi tiga bagian yaitu, pekerjaan setelah berkembangnya Ekowisata Air Terjun Suranadi, pekerjaan sampingan setelah berkembangnya Ekowisata Air Terjun Suranadi dan usaha atau bisnis yang dimiliki stelah berkembangnya Ekowisata Air Terjun Suranadi.

Dampak Pengembangan Ekowisata Air Terjun Suranadi Terhadap Pekerjaan Utama Masyarakat Dusun Gunung Sari Umakayu Desa Jatiluwih. Dalam penelitian ini jenis - jenis pekerjaan utama akan dikelompokan menjadi lima bagian yang digunakan untuk mengetahui pekerjaan utama masyarakat sesudah berkembangnya Ekowisata Air Terjun Suranadi.

Tabel 6. Pekerjaan Utama Masyarakat Dusun Gunung Sari Umakayu Desa Jatiluwih

\begin{tabular}{|l|c|c|c|c|}
\hline \multirow{2}{*}{$\begin{array}{c}\text { Pekerjaan } \\
\begin{array}{c}\text { Sesudah } \\
\text { Berkembangnya } \\
\text { Ekowisata Air } \\
\text { Terjun Jatiluwih }\end{array}\end{array}$} & $\begin{array}{c}\text { Jumlah } \\
\text { Responden }\end{array}$ & $\begin{array}{c}\text { Persentase } \\
(\%)\end{array}$ & $\begin{array}{c}\text { Jumlah } \\
\text { Responden }\end{array}$ & $\begin{array}{c}\text { Persentase } \\
(\%)\end{array}$ \\
\hline Pengangguran & 0 & 0 & 4 & 5 \\
\hline Petani & 17 & 68 & 36 & 48 \\
\hline Pedagang & 3 & 12 & 2 & 3 \\
\hline PNS & 3 & 12 & 3 & 4 \\
\hline Lainnya & 2 & 8 & 30 & 40 \\
\hline Jumlah Total & 25 & 100 & 75 & 100 \\
\hline
\end{tabular}

Berdasarkan Tabel dapat dilihat bahwa masyarakat Dusun Gunungsari Umakayu Desa Jatiluwih memiliki jenis - jenis pekerjaan yang berbeda - beda diantaranya yaitu ada yang sebagai petani, pedagang, PNS dan pekerjaan lainya, sesudah berkembangnya Ekowisata Air Terjun Suranadi. Masyarakat didalam kelompok yang menjadi pengangguran dan memiliki pekerjaan lainya mendapat nilai terendah dengan persentase $0 \%$, sedangkan pekerjaan sebagai petani yang didalam kelompok memiliki nilai tertinggi yaitu 17 Orang dengan 
jumlah persentase 68\%, masyarakat yang bermata pencaharian sebagai pedagang hanya 3 Orang dengan jumlah persentase $12 \%$ begitu juga masyarakat yang dalam kelompok memiliki pekerjaan sebagai PNS hanya 3 Orang dengan jumlah persentase $12 \%$, beda halnya dengan masyarakat Dusun Gunungsari Umakayu yang ada di luar daripada kelompok Ekowisata Air Terjun Suranadi, adanya 4 Orang sebagai pengangguran dengan jumlah persentase $5 \%$, sama halnya didalam kelompok dengan diluar kelompok yang memiliki nilai tertinggi yaitu masyarakat dengan pekerjaan sebagai petani yaitu 36 Orang dengan jumlah persentase $48 \%$, sebagai pedagang hanya 2 Orang dengan jumlah persentase $3 \%$, yang sebagai PNS hanya 3 Orang dengan jumlah persentase 4\%, Adanya peningkatan setelah berkembangnya Ekowisata Air Terjun Suranadi, didalam maupun diluar kelompok tidak adanya pengangguran. Diluar kelompok yang dimaksud dengan pekerjaan lainya, yang dimaksudkan dengan pekerjaan lainya disini meliputi ada yang sebagai karyawan swasta, penebangkayu, bengkel. Sebagai buruh selip beras, adajuga yang sebagai buruh bangunan, guide, waiter dan waitress.

Dampak pengembangan pariwisata terhdap pekerjaan sampingan digunakan untuk mengetahui seberapa banyak Masyarakat yang memiliki pekerjaan sampingan setelah berkembangnya Ekowisata Air Terjun Suranadi.

\section{Tabel 7. Pekerjaan Sampingan Masyarakt} Sesudah Berkembang

\begin{tabular}{|c|c|c|c|c|}
\hline \multirow{2}{*}{$\begin{array}{c}\text { Pekerjaan } \\
\text { Sampingan } \\
\text { Sesudah } \\
\text { Berkembann } \\
\text { ya Ekowisata } \\
\text { Air Terjun } \\
\text { Suranadi }\end{array}$} & \multicolumn{2}{|c|}{ Di Dalam } & \multicolumn{2}{|c|}{ Di Luar } \\
\hline & $\begin{array}{l}\text { Jumlah } \\
\text { Respond } \\
\text { en }\end{array}$ & $\begin{array}{c}\text { Persenta } \\
\text { se } \\
(\%)\end{array}$ & $\begin{array}{l}\text { Jumlah } \\
\text { Respond } \\
\text { en }\end{array}$ & $\begin{array}{c}\text { Persenta } \\
\text { se } \\
(\%)\end{array}$ \\
\hline $\mathrm{Ya}$ & 25 & 100 & 26 & 35 \\
\hline Tidak & 0 & 0 & 49 & 65 \\
\hline Jumlah Total & 25 & 100 & 75 & 100 \\
\hline
\end{tabular}

Sumber : Hasil Penelitian 2017

Berdasarkan Tabel dapat dilihat bahwa sesudah berkembangnya Ekowisata Air Terjun Suranadi, masyarakat Dusun Gunungsari Umakayu Desa Jatiluwih diluar kelompok yang memiliki pekerjaan sampingan diantaranya sebagai tukang bangunan, penebang kayu, berternak sapi, guide anventure motor kros, berkebun menanam sayur - sayur dan bertani. Setelah berkembangnya Ekowisata Air Terjun Suranadi adanya peningkatan pekerjaan sampingan yang dimiliki didalam klompok dan diluar kelompok, meskipun diluar kelompok yang memiliki pekerjaan sampingan tidak begitu bertambah.

Dampak pengembangan pariwisata terhadap masyarakat yang memiliki suatu usaha atau bisnis digunakan untuk mengetahui seberapa banyak masyarakat yang memiliki suatu usaha atau bisnis dari sesudah berkembangnya Ekowisata Air Terjun Suranadi.

Tabel 8. Masyarakat Yang Memiliki Usaha/Bisnis Sesudah Berkembang

\begin{tabular}{|c|c|c|c|c|}
\hline Memiliki & \multicolumn{2}{|c|}{ Di Dalam } & \multicolumn{2}{|c|}{ Di Luar } \\
\hline $\begin{array}{l}\text { Sesudah } \\
\text { Berkembangnya } \\
\text { Ekowisata Air } \\
\text { Terjun Suranadi }\end{array}$ & $\begin{array}{c}\text { Jumlah } \\
\text { Responden }\end{array}$ & $\begin{array}{c}\text { Persentase } \\
(\%)\end{array}$ & $\begin{array}{c}\text { Jumlah } \\
\text { Responden }\end{array}$ & $\begin{array}{c}\text { Persentase } \\
(\%)\end{array}$ \\
\hline $\mathrm{Ya}$ & 2 & 8 & 5 & 7 \\
\hline Tidak & 23 & 92 & 70 & 93 \\
\hline Jumlah Total & 25 & 100 & 75 & 100 \\
\hline
\end{tabular}

Berdasarkan Tabel dapat dilihat bahwa sesudah berkembangnya Ekowisata Air Terjun Suranadai Usaha - usaha atau bisnis yang dimiliki masyarkata Dusun Gunungsari Umakayu, didalam maupun diluar kelompok Ekowisata Air Terjun Suranadi, dari hasil kuesioner dan wawancara dapat dilihat tidaklah sangat berpengaruh besar terhadap peluang bisnis atau usaha yang dimiliki masyarakat, usaha yang dimilki masyarakat terdiri dari usaha, jual beli sapi, jual beli ternak babi, jual pakan ternak, usaha selip beras dan usaha bengkel motor.

\section{SIMPULAN DAN SARAN}

\subsection{Simpulan}

1. Pengembangan Ekowisata Air Terjun Suranadi di Desa Jatiluwih berdasarkan indikator diantaranya adanya produk Ekowisata Air Terjun Suranadi, potensi, daya tarik, fasilitas dan aksesibilitas, tingkat kunjungan wisatawan, interaksi antar wisatawan dengan masyarakat, atraksi dan keterlibatan masyarakat dalam pengembangan pariwisata berada pada konsep Tipologi Patisipasi Insentif dan Tipologi fartisipasi fungsional. Masyarakat Dusun Gunungsari Umakayu, Desa Jatiluwih adanya pembuatan kelopok Ekowisata dimana kelompok itu sendiri berpartisipasi dengan memberikan sumber daya yang mereka miliki seperti pembuatan akses jalan menuju Air Terjun 
Suranadi, lahan parkir, fasilitas utuk wisatawan sperti adanya pembuatan toilet dan pembuatan tempat duduk untuk beristirahat di tengah perjalan menuju daya tarik wisata Air Terjun dan pembuatan balae bengo di lokasi Air Terjun.

Dampak Ekonomi masyarakat sebelum dan sesudah berkembangnya Ekowisata Air Terjun Suranadi, diluar kelompok dan didalam kelompok Ekowisata Air Terjun Suranadi indikator yang digunakan yaitu dampak terhadap pendapatan masyarakat di dalam kelompok dan di luar kelompok, dampak terhadap kesempatan kerja masyarakat didalam dan diluar kelompok Ekowisata Air Terjun Suranadi. Dari hasil kuesioner dampak terhadap pendapatan masyarakat yang didalam dan diluar kelompok menunjukan bahwa setelah berkembangnya Ekowisata Air Terjun Suranadi terjadinya jumlam pendapatan rata rata perbulan, jumlah pengeluaran untuk memenuhi kebutuhan sehari - hari dan kecukupan jumlah pendapatan untuk memenuhi kebutuhan sehari - hari, didalam kelompok mengalami peningkatan sedangkat diluar kelompok tidak semuanya masyarakat mengelami peningkatan.

Dampak terhadap kesempatan kerja setelah berkembangnya Ekowisata Air Terjun Suranadi jumlah pengangguran didalam dan diluar kelompok berkurang, masyarakat yang ada didalam kelompok setelah berkembangnya Ekowisata Air Terjun Suranadi memiliki pekerjaan sampingan bahkan memiliki usaha penyewaan homestay yang bergiliran terhadap anggota kelompok, namun yang ada diluar kelompok tidak semunya mempunya pekerjaan sampingan, masyarakat diluar kelompok juga lebih mementingkan ternak dan panen padinya, pekerjaan sampingan hanya mereka lakukan apabila padi mereka sudah panen.

\subsection{Saran}

1. Untuk pihak pengelola Ekowisata Air Terjun Suranadi dan beserta kelompok, sebaiknya peran serta masyarakat lokal ditingkatkan agar tidak terjadinya tumpang tindih antar di dalam kelompok dan di luar kelompok, adanya sosialisasi atar masyarakat, agar adanya peluang pekerjaan sampingan untuk semua masyarakat, adanya pendapatan masyarakat yang merata. Bahkan Karana berkembangnya Ekowisata Air terjun Suranadi bisa dirasakan oleh semua masyarkat Dusun Gunung Sarai Umakayu begitu juga dengan Desa Jatiluwih.

2. Untuk pihak masyarakat diharapkan memberikan dukungan tentunya akan semakin mengoptimalkan pengambangan Ekowisata Air Terjun Suranadi. Masyarakat harus lebih meningkatkan dan mempererat kerukunan, gotong - royong dan prsatuan, apabila bisa ikut serta dalam kelompok seperti masyarakat lainya yang sudah bergabung/ada di dalam kelompok daya tarik Ekowisata Air Terjun Suranadi, sehingga kedepannya dapat meningkatkan perekonomian masayarakat keseluruhan di Dusun Gunungsari Umakayu, Desa Jatiluwih.

3. Saran selanjutnya perlu adanya strategi pemasaran yang lebih untuk Ekowisata Air Terjun Suranadi agar kedepannya dapat meningkatkan kunjungan wisatawan asing, karana pada saat ini kunjungan untuk wisatawan asing ke Ekowisata Air Terjun Suranadi masih sangat rendah.

\section{DAFTAR PUSTAKA}

Agus Alim. 2002. Pengembangan Air Terjun Munduk Sebagai Potensi Objek Wisata Alam Di Desa Munduk Kecamatan Banjar Kabupaten Buleleng. Denpasar: Sekripsi Fakultas PariwisataUniversitas Udayana.

Arida, Sukma. 2009. Meretas jalan ecowisata Bali. Denpasar: Udayanan Press.

Adikampana, I Made. 2008.Pengaruh Pariwisata Alam Di Taman Nasional Bali Barat Terhadap Peluang Pekerjaan Bagi Masyarakat Loka. Jurnal Vol.3. Yogyakarta : Universitas Gajah Mada.

Adikampana, I Made. 2014. Tentang Pengembangan Pariwisata Di Daerah Pinggiran. Jurnal Vol. 5. Fakultas Pariwisata : Universitas Udayana.

Bungin, Burhan, 2007. Penelitian Kualitatif Komunikasi, Ekonomi, Kebijakan Publik, dan Ilmu Sosial Lainnya. Jakarta : Kencana Prenada Media Group.

Dritasto, A dan Annisa Ayu. 2013. Analisis Dampak Ekonomi Wisata Bahari Terhadap Pendapatan Masyarakat di Pulau Tidung. Jurnal Vol. 20. Bandung: Institut Teknologi Nasional .

Gunawan, Imam. 2013. Metode Penelitian Kualitatif Teori dan Praktik. Jakarta : Bumi Aksara.

I Gusti Made Satria Adiguna. 2013. Dampak Pengembangan Pariwisata Terhadap Ekonomi Masyarakat Desa Canggu Kecamatan Kuta Utara Kabupaten Badung. Denpasar: Sekripsi Fakultas Pariwisata Universitas Udayana. 
Muslich, 2010. Metode Pengambilan Keputusan Kuantitatif : Jakarta, Bumi Aksara, 2010.

Nasir, Mohammad. 1988. Metode Penelitian. Jakarta : Ghalia Indonesia

Nawami. H. Hadiri, 1995. Metode Penelitian Bidang Sosial. Yogyakarta : Gajahmada University Press.

Noor, Juliansyah. 2011. Metodologi Penelitian. Jakarta : Penerbit Kencana.

Rusdiana. 2014. Pemanfaatan Potensi Desa Jatiluwih Kecamatan Penebel Kabupaten Tabanan Sebagai Obyek Wisata Alam. Jurnal Pendidikan Geografi. vol 5 No. 1.

Sugiyono. 2014. Metode Penelitian Kuantitatif Kualitatif dan R\&D. Bandung : Alpabeta.

Sugiyono. 2010. Metode Penelitian Pendidikan Pendekatan Kuantitatif, Kualitatif, dan R\&D. Bandung : Alfabeta.

Sugiarto, Ronny. 2000. Pariwisata Antara Obsesi dan Realita. Yogyakarta : Adicita Karya Nusa.

Wayan Kurniawan. 2015. Dampak Sosial Ekonomi Pembangunan Pariwisata Umbul Sidomukti kecamatan Bandungan Kabupaten Semarang. Semarang: Sekripsi Fakultas Ekonomi Universitas Negeri Semarang.

Pretty, Jules. 1995. Participatory Learning For Suistainable Agriculture. Word Development.

Suwena, I Ketut \& Widyatmaja, I Gst Ngr. 2010. Ilmu Pariwisata. Denpasar : Universitas Udayana.

Soekanto, Soerjono. 1975. Sosiologi Suatu Pengantar. Jakarta : Yayasan Penerbitan Universitas Indonesia.

Pitana, I Gde dan Gayatri, P. 2005. Sosiologi Pariwisata. Yogyakarta : Penerbit Andi 